\title{
DESCRIPTION OF TWO APPARENTLY NEW FLYCATCHERS FROM COSTA RICA.
}

\author{
BY \\ George K. Cherrie. \\ Ornithologist, Museo Nacional de Costa Rica.
}

A single specimen before me seems to be intermediate in many characters between the genera Mionectes and Leptopogon as defined by Salvin and Godman in their Biologia Centrali-Americana. But from the rather close general resemblance (of the lower parts especially) to Mionectes assimilis, and the very small feeble rictal bristles, it is probably best placed with Mionectes.*

The third, fourth, and fifth primaries are longest and nearly equal; second equal to the sixth; first shorter than the longest secondaries.

For this apparently new Flycatcher I propose the name

Mionectes semischistaceus sp. nov.

Type: Adult female (No. 6432, $\nmid$ Museo Nacional de Costa Rica, Guayabal, Costa Rica, February 24, 1891; C. F. Underwood). Above, whole head, neck, and upper back, including scapulars and lesser wing-coverts, slate-gray, perhaps a little darker on the head; lower back, rump, and upper tail-coverts deep olive-green, the transition from the slate-gray to the olive-green rather abrupt. Wings and tail blackish or dusky edged with olive-green, that on the wings having a slightly yellowish or ochraceous shade. Below, chin, upper throat, and sides of head slate-gray, ligher than the back; breast olive-greenish, with a decided shading of orange-ochraceous, the latter color deepening and the former fading and disappearing posteriorly on the sides, belly, and crissum; the center of the abdomen is almost clear ocher-yellow. Under wing-eoverts orangeochraceous.

Length (skin), $5.06^{\prime \prime}$; wing, $2.35^{\prime \prime}$; tail, $2.13^{\prime \prime}$; tarsus $0.60^{\prime \prime}$; gonys, $0.26^{\prime \prime}$; width of bill at nostrils, $0.20^{\prime \prime}$; the maxilla is broken away close to the nostrils.

The only species of Leptopogon or Mionectes with which I have had opportunity to compare directly are L. pileatus, M. assimilis and M. olivaceus.

*Without doubt correctly referred to Mionectes, and a very distinct species.-R. R.

$\nmid$ No. 124616, U. S. National Museum, br the courtesy of the Costa Rica National Museum. 
I have two specimens from the southwest coast of Costa Rica (Pozo Azul) that do not seem referable to any of the species of which I find lescriptions, of either the genus Ornithion or Tyrannulus. I say of either genus, because the two genera seem to me very closely allied and the birds in hand might probably be referred as reasonably to the one genus as to the other. However, the bill in T. brunneicapillus (the only species which I have to compare with) is heavier, deeper, and not so loroad at the base. The examples before me have the nostrils placed in the middle of a membrane and the rictal bristles only very feebly developed; wing rather short, somewhat rounded; tail square.

\section{Ornithion pusillum subflavum subsp. nov.}

Type: Adult female (No. 5980,* Museo Nacional de Costa Rica, Pozo Azul, Costa Rica, May 8, 1891; C. F. Underwood). Above ashy or dusky olive-green, cap dusky blackish, loral region, line on upper and lower eyelids, malar region, and anterior part of auriculars ashy whitish; a blackish spot (same color as crown) behind the eye. Wings and tail dusky; greater and middle wing-coverts tipped with olive-yellowish, forming two rather conspicuous bars, secondaries edged externally with pale yellowish. Rectrices narrowly tipped with pale yellowish. Below, chin and upper throat ashy-whitish, darkening on the lower throat and breast into olive and yellowish. Belly and crissum bright primrose yellow. Under wing-coverts primrose yellow. Inner edges of primaries and secondaries whitish, with a yellowish shade on the latter.

Length (skin ), 3.66; wing, 1.90 ; tail, 1.64 ; exposed culmen, 0.33 tarsus, 0.58 .

The second example (No. 5979, Museo Nacional de Costa Rica, Pozo Azul, Costa Rica, May 9, 1891), is a male in moulting plumage, the rectrices just appearing beyond their coverts. The wing and tail feathers are more blackish and the plumage as a whole fresher and brighter.

Museo Nacional,

San José de Costa Rica, September 2, 1891.

*No. 124617 , U. S. National Museum. This bird comes very close to 0 . pusillum Cab., from Panama, but is much more distinctly yellow underneath, and should, I think, be separated as a local race or subspecies.-R. R. 


\section{$2 \mathrm{BHL}$ Biodiversity Heritage Library}

Cherrie, George Kruck. 1892. "Description of two apparently new flycatchers from Costa Rica." Proceedings of the United States National Museum 15(888), 27-28. https://doi.org/10.5479/si.00963801.888.27.

View This Item Online: https://www.biodiversitylibrary.org/item/53607

DOI: https://doi.org/10.5479/si.00963801.888.27

Permalink: $\underline{\text { https://www.biodiversitylibrary.org/partpdf/52680 }}$

\section{Holding Institution}

Smithsonian Libraries

\section{Sponsored by}

Smithsonian

\section{Copyright \& Reuse}

Copyright Status: Public domain. The BHL considers that this work is no longer under copyright protection.

This document was created from content at the Biodiversity Heritage Library, the world's largest open access digital library for biodiversity literature and archives. Visit BHL at https://www.biodiversitylibrary.org. 